\title{
CUIDADOS AOS PACIENTES PÓS COVID EM USO DE VENTILAÇÃO NÃO INVASIVA: RELATO DA EXPERIÊNCIA DO ENFERMEIRO
}

\section{Rozemy Magda Vieira Goncalves ${ }^{1}$, Terezinha de Fátima Gorreis', Elisangela Souza1}

\section{(E- mail rozygong@gmail.com)}

\section{Hospital de Clínicas de Porto Alegre}

No ano de 2019 foi identificado na região central da China o novo coronavírus. Covid-19 é a expressão clínica da infecção pelo vírus zoonótico SARS-CoV-2, um betacoronavírus RNA de cadeia simples. A doença foi reconhecida após investigação epidemiológica e microbiológica de um cluster de pneumonia que afeta os indivíduos, sendo assintomáticos ou com manifestações graves, incluindo a síndrome respiratória aguda. Neste contexto, a Ventilação Mecânica não Invasiva (VNI) é um suporte ventilatório que visa diminuir o trabalho respiratório, permitindo o repouso dos músculos respiratórios e promovendo a reabilitação para a alta. O 6ํaㅁ andar Norte do Hospital de Clínicas de Porto Alegre (HCPA) possui leitos de Cuidados Especiais (UCE) para Pneumologia que atende pacientes com sequelas ou doenças pulmonares decorrentes do Covid-19. Relatamos a experiência de enfermeiras da UCE de pneumologia, relacionando os cuidados a pacientes pós Covid -19 e que necessitam do suporte de VNI de forma apropriada. A UCE pneumologia recebe pacientes com necessidade do uso de VNI contínua ou intermitente. Os enfermeiros passaram por treinamentos relativos aos cuidados, instalando a VNI livre de escapes de ar, realizando adaptação do circuito do aparelho à máscara e ao paciente através do fixador cefálico, escolhendo a máscara ideal observando a anatomia do paciente, mantendo os parâmetros do aparelho conforme estabelecido pela fisioterapia, instalando filtros de barreira para evitar contaminações, com data e troca a cada 7 dias ou quando sujidade e umidade. Se o aparelho não possuir sistema próprio de oxigênio, um dispositivo deve ser adaptado ao sistema (introduzir no circuito por adaptação proveniente da rede). 0 enfermeiro deve ainda, instalar e desinstalar a VNI nos horários previamente combinados e avaliar o paciente com frequência observando o padrão ventilatório e a oximetria. Por fim, realizando a educação do paciente e familiares em relação ao uso do equipamento (tanto em ambiente hospitalar quanto domiciliar), estimulando o autocuidado e adesão à terapia. O Enfermeiro desenvolve papel essencial na reabilitação dos pacientes acometidos pela Covid-19. Deve estar atento a evolução da doença, reconhecendo de imediato sinais e sintomas que indiquem piora clínica, assim como, estar capacitado a realizar educação do paciente e família durante a terapia com VNI e manejo dos equipamentos e adaptações necessárias a tal terapia.

Nota da Comissão Organizadora: O presente resumo foi aceito para publicação no XIII Simpósio Brasileiro de Microbiologia Aplicada em caráter de excepcionalidade devido à pandemia de COVID-19

Palavras - chave: Covid-19; Ventilação não Invasiva; Cuidados de Enfermagem; Pneumologia 